\title{
PENGARUH KONSUMSI SAYUR BUAH PEPAYA TERHADAP KELANCARAN AIR SUSU IBU (ASI) DI WILAYAH KERJA PUSKESMAS WAY KANDIS KOTA BANDAR LAMPUNG
}

\author{
Yessi Aprianti ${ }^{1}$, Rilyani ${ }^{2}$, Usastiawaty Cik Ayu Saadiah Isnainy ${ }^{3^{*}}$ \\ ${ }^{1}$ Mahasiswa Program Studi Keperawatan Universitas Malahayati \\ Email:yessiaprianti88@gmail.com \\ ${ }^{2,3}$ Dosen Keperawatan Universitas Malahayati \\ Email:simahayarily@gmail.com
}

\section{ABSTRACT: THE INFLUENCE OF PAPAYA FRUIT CONSUMPTION TO BREASTMILK PRODUCTION SMOOTHNESS IN WAY KANDIS PUBLIC HEALTH CENTER OF BANDAR LAMPUNG}

Introduction: breastmilk is a special food made for babies. The nutrition content of breastmilk is very perfect according to the needs of growing and developing of the babies. Lactogen is a substance that is able to improve the breastmilk production. Papaya fruit is a fruit containing lactogen with a potential to stimulate oxytocin and prolactin hormones that are useful in improving the breastmilk production.

Objective: the objective of this research was to find out the influence of papaya fruit consumption to breastmilk production smoothness in Way Kandis public health center of Bandar Lampung in 2019.

Method: this was a quantitative research with quasi-experiment method and one group pretest and posttest design. Population was 80 breastfeeding post-partum mothers until day 40.30 respondent samples were taken by using random sampling. Data were analyzed by using dependent $t$-test.

Results: The average production scores of breastmilk before and after treatment were 2.87 and 5.97 respectively. The statistic test result derived $p$-value 0.000 $<$ a 0.05 . The conclusion was that there was an influence of papaya fruit consumption to breastmilk production smoothness in Way Kandis public health center of Bandar Lampung in 2019. The researcher suggests the health workers to provide health counseling in each pregnant mother examination, and to provide health education concerning the way to improve breastmilk by consuming papaya fruit, so that mothers would have knowledge concerning the benefits of papaya fruit in improving breastmilk production.

Keywords : papaya fruit consumption, breastmilk production smoothness, breastfeeding mothers 


\section{INTISARI: PENGARUH KONSUMSI SAYUR BUAH PEPAYA TERHADAP KELANCARAN AIR SUSU IBU (ASI) DI WILAYAH KERJA PUSKESMAS WAY KANDIS KOTA BANDAR LAMPUNG}

Pendahuluan:Air susu ibu (ASI) merupakan makanan untuk khusus dibuat untuk bayi. Kandungan gizi dari ASI sangat sempurna serta sesuai dengan kebutuhan tumbuh kembang bayi. Laktagogum merupakan zat yang yang dapat meningkatkan atau memperlancar produksi ASI. Buah pepaya merupakan jenis tanaman yang mengandung laktagogum memiliki potensi dalam menstimulasi hormon oksitosin dan prolaktin yang berguna dalam meningkatkan dan memperlancar produksi ASI.

Tujuan: Diketahui Pengaruh Konsumsi Sayur Buah Pepaya Terhadap Kelancaran ASI Diwilayah Kerja Puskesmas Way Kandis Kota Bandar Lampung Tahun 2019.

Metode:Jenis penelitian ini adalah Kuantitatif. Desain penelitian metode Quasi Eksperimental dengan pendekatan One group pretest - posttest design. Populasi sebanyak 80 responden, sampel yang digunakan adalah 30 ibu post partum yang menyusui sampai 40 hari, pengambilan sampel pada penelitian adalah random sampling Uji statistik menggunakan uji t-tes dependen.

Hasil Penelitian: rata-rata produksi ASI sebelum tindakan adalah 2.87, rata-rata produksi ASI sesudah tindakan adalah 5,97, hasil uji statistik didapatkan nilai 0,000 ( $P$ value $=0,000$, dimana $P$ value $<a(0,05)$ maka dapat disimpulkan ada pengaruh mengkonsumsi sayur buah pepaya terhadap produksi ASI pada ibu menyusui Di Wilayah Kerja Puskesmas Way Kandis Kota Bandar Lampung Tahun 2019. Saran kepada petugas kesehatan agar dapat melakukan konseling pada setiap pemeriksaan ibu hamil, serta memberikan penyuluhan tentang cara meningkatkan produksi ASI dengan mengkonsumsi olahan sayur buah pepaya. Sehingga memiliki pengetahuan tentang manfaat yang cukup terhadap buah pepaya dalam meningkatkan produksi ASI

Kata Kunci : Konsumsi buah pepaya, kelancaran ASI, Ibu menyusui

\section{PENDAHULUAN}

Pertumbuhan

dan

perkembangan anak merupakan hasil interaksi antara faktor genetika dan lingkungan. Pada masa post natal faktor yang mempengaruhi kualitas tumbuh kembang salah satunya adalah faktor gizi dimana pada usia bayi yang berperan adalah air susu ibu (ASI). ASI adalah makanan untuk bayi dan khusus dibuat untuk bayi. Kandungan gizi dari ASI sangat khusus dan sempurna serta sesuai dengan kebutuhan tumbuh kembang bayi (Maryunani, 2012).

Masa nifas merupakan proses alamiah yang dialami wanita setelah melahirkan. Masa nifas berlangsung selama kira-kira 6 minggu. Pada masa ini terjadi perubahan-perubahan fisiologis dan psikologis, yaitu perubahan fisik, involusi uterus, kekentalan darah kembali normal, dan terjadi perubahan psikis taking in, taking hold, letting go dan proses laktasi atau menyusui (Saleha, 2009). Laktasi merupakan suatu masa dimana terjadi perubahan pada payudara ibu, pada hari kedua atau tiga pasca persalinan, kadar estrogen dan progesteron turun drastis, sehingga pengaruh prolaktin lebih dominan dan pada saat inilah mulai terjadi sekresi ASI (Ambarwati, 2010).

Dengan menyusukan lebih dini terjadi perangsangan puting susu, terbentuklah prolaktin oleh hipofisis sehingga sekresi ASI semakin lancar. Pada saat tersebut payudara secara tiba-tiba menjadi lebih besar, lebih 
keras, dan lebih peka yang menyebabkan rasa nyeri yang berdenyut pada payudara (Aryanti Wardiyah dan Rilyani, 2016).

World Health Organization (WHO) merekomendasikan hanya memberikan air susu ibu saja pada bayi selama 6 bulan pertama (ASI Ekslusif) yang dilanjutkan hingga anak berusia 2 tahun. Hal ini karena ASI merupakan makanan bayi alamiah yang kaya nutrisi, mengandung faktor imunologis, dan memiliki bioavaibilitas yang lebih tinggi bila dibandingkan susu formula. Berbagai penelitian menunjukan bahwa pemberian ASI sangat menguntungkan ditinjau dari segi kesehatan dan sosioekonomi, termasuk menurunkan angka kesakitan serta kematian bayi WHO (dalam Kharisma dkk, 2011). Menurut data United Nations Childrens Fund (UNICEF) cakupan ASI ekslusif di seluruh dunia hanya $41 \%$ selama periode 2017-2018.

Menurut Survei Demografidan Kesehatan Indonesia (SDKI) tahun 2017, Angka Kematian Bayi sebesar 24 kematian per 1000 kelahiran hidup. Angka ini masih cukup tinggi jika dibandingkan dengan negara-negara tetangga di kawasan ASEAN sehingga menjadikan Indonesia menjadi peringkat kedua tertinggi di ASEAN.

Riset Kesehatan Dasar

Kementrian Kesehatan RI tahun 2018 menyebutkan bahwa $6,2 \%$ bayi di Indonesia lahir dengan barat badan rendah (<2500 gram), $17,7 \%$ dengan gizi kurang, $22,7 \%$ dengan balita pendek. Permasalahan kurang gizi ini merupakan permasalahan besar yang dihadapi bangsa Indonesia. Upaya untuk memutuskan rantai kekurangan gizi kepada 1000 Hari Pertama Kehidupan (HPK) dapat diputuskan melalui upaya salah satunya dengan ASI Eklusif.

Kebijakan pemerintah Indonesia dalam pemberian ASI ini juga diperkuat dengan undang-undang kesehatan no 36 tahun 2009 pasal 128 tentang pemberian ASI ekslusif dimana ayat 1 menegaskan bahwa setiap bayi berhak mendapatkan air susu ibu secara ekslusif sejak dilahirkan selama 6 (enam) bulan kecuali atas indikasi medis (Maryunani, 2012). Upaya lain yang telah dilakukan pemerintah dalam mendukung pemberian ASI adalah dengan dikeluarkannya Peraturan pemerintah no 33 tahun 2012 tentang pemberian ASI eksklusif yaitu pada pasal 2 dimana ayat 1 menegaskan bahwa pemberian ASI ekslusif bertujuan untuk menjamin penuh hak bayi untuk mendapatkan ASI ekslusif sejak dilahirkan sampai enam bulan dengan memperhatikan pertumbuhan dan perkembangan (Peraturan Pemerintah RI, 2012). Oleh karena itu, bayi yang berumur kurang dari enam bulan dianjurkan hanya diberi ASI tanpa tambahan cairan dan makanan pendamping. Setelah 6 bulan baru mulai diberikan makanan pendamping ASI.

Akan tetapi, dalam kenyataannya cakupan ASI di negara Indonesia sudah melampaui target yang diharapkan seperti pada tahun 2011 cakupan ASI di Indonesia ada $61,50 \%$, kemudian mengalami penurunan pada tahun 2012 menjadi 48,62\%. Tahun 2013 cakupan ASI di Indonesia mengalami peningkatan dari cakupan ASI tahun 2012 yaitu sebesar 54,3\% kemudian terjadi penurunan kembali pada tahun 2014 yaitu menjadi $52,30 \%$, pada tahun 2015 meningkat menjadi 55,7\%, tahun 2016 menjadi 54,0\%, dan mengalami peningkatan menjadi 61,33\% (Kementrian Kesehatan RI, 2017).

Secara nasional cakupan ASI ekslusif di Indonesia tahun 2017 sebesar $61,33 \%$, angka tersebut sudah melampaui target renstra tahun 2017 yaitu sebesar 44\%. Di Indonesia pada tahun 2017 dengan cakupan ASI ekslusif tertinggi terdapat di Provinsi Nusa Tenggara Barat (87,35\%). Sedangkan cakupan terendah 
terdapat pada Provinsi Papua $(15,32 \%)$ dan di Provinsi Lampung berada pada urutan ke 11 dengan cakupan ASI eklusif (64,98\%). Akan tetapi masih terdapat lima provinsi yang belum mencapai target Renstra ASI ekslusif tahun 2017 (Kementrian Kesehatan RI, 2017).

Bandar Lampung sendiri dari tahun ke tahun memiliki cakupan ASI ekslusif yang menurun seperti pada tahun 2015 cakupan ASI eklusif di Bandar Lampung sebanyak 66,6\%. Tahun 2016 mengalami penurunan sebanyak 58,89\% kemudian pada tahun 2017 mengalami peningkatan lagi yaitu 62,07\%. Pada tahun 2018 angka cakupan ASI di Bandar Lampung meningkat menjadi $62,46 \%$. Pencapaian ASI ekslusif dikota Bandar Lampung tahun 2018 sudah melebihi target yang diharapkansebesar 45\% (Dinas Kesehatan Kota Bandar Lampung, 2018).

ASI sebagai makanan yang terbaik bagi bayi dan tidak perlu diragukan lagi, namun akhir-akhir ini sangat disayangkan banyak diantara ibu menyusui melupakan keuntungan menyusui (Aryanti Wardiyah dkk). Banyak manfaat yang didapat dari pemberian ASI bagi bayi dan ibu menyusui. Pada ASI mengandung antibodi dalam jumlah besar yang berasal dari ibu. Antibodi tersebut membantu bayi menjadi tahan terhadap penyakit dan meningkatkan sistem kekebalan tubuh bayi. Telah terbukti bayi yang diberi ASI lebih kuat dan terhindar dari beragam penyakit seperti asma, pneumonia diare, infeksi telinga, alergi, multiple scleroses, radang usus buntu dan obesitas. Disamping itu pemberian ASI oleh ibu menyusi merupakan cara paling mudah untuk menurunkan berat badan ibu. Wanita yang menyusui memiliki insiden lebih kecil terkena osteoporosis, kanker payudara dan ovarium (Sri Banun dkk, 2015). $\begin{array}{lcc}\text { Data Dinas Kesehatan Kota } & \text { Kotan } \\ \text { Bandar Lampung tahun } & 2018 \\ \text { mencatat wilayah kota Bandar }\end{array}$ Lampung terdiri dari 31 wilayah puskesmas, dimana terdapat 3 puskesmas dengan cakupan ASI ekslusif terendah yaitupada wilayah puskesmas Way Kandis, puskesmas Labuhan Ratu dan puskesmas Way Kandis dengan cakupan ASI sebesar 33,54\%. Target ASI ekslusif di Puskesmas Way Kandis pada tahun 2018 sebesar 80\% tetapi cakupan yang dapat dicapai hanya sebesar $32,2 \%$. Jumlah tersebut sangat jauh dari target yang diharapkan Puskesmas Way Kandis.

Puskesmas Way Kandis dalam rangka meningkatkan cakupan ASI mengadakan pendataan langsung ASI eklusif di wilayahnya terhadap 5 kelurahan dengan pendataan satu tahun 2 kali yaitu tiap bulan Februari dan Agustus serta memberikan promosi kesehatan mulai dari keluarga-keluarga serta membuat baliho mengenai ASI eklusif. Rendahnya cakupan ASI eklusif dikarenakan kurangnya produksi ASI yang baik, hal tersebut yang menjadikan ASI eklusif masih menjadi suatu masalah yang besar disuatu daerah tersebut, salah satunya Kecamatan Way Kandis yang menjadi cakupan ASI terendah di Kota Bandar Lampung.

Hasil studi pendahuluan yang dilakukan di Puskesmas Way Kandis pada tanggal 12 Februari 2019 terhadap 10 orang ibu menyusui, terdapat $70 \%$ ibu yang tidak menyusui bayinya secara ekslusif karena ibu merasa ASI nya tidak cukup, dibuktikan dengan adanya bayi yang menangis setiap selesai menyusu, serta banyak ibu nifas di daerah tersebut yang pengeluaran ASI nya kurang lancar dikarenakan kurangnya asupan nutrisi yang seimbang (buahbuahan, sayur-sayuran), pengetahuan yang kurang, ekonomi keluarga serta psikologis ibu yang kurang percaya 
diri ketika memberikan ASI kepada bayinya, 2 orang ibu menyusui yang tidak menyusui bayinya secara ekslusif karena ibunya bekerja, dan 1 orang ibu menyusui bayinya secara ekslusif. Hal ini disebabkan karena kurangnya pengetahuan ibu untuk bisa meningkatkan produksi ASI nya tanpa harus menambahkan susu formula.

Terdapat berbagai jenis tanaman yang berkhasiat sebagai tanaman obat. Beberapa diantaranya berkhasiat sebagai laktagogum sepeti tanaman katuk, lampes, adas manis, bayam duri, bidara upas, blustru, kelor, nangka, temulawak dan pepaya muda. Seperti pada penelitian yang dilakukan oleh Gunanegara (2010) yang menunjukkan bahwa pemberian ekstrak daun katuk berpengaruh terhadap peningkatan produksi ASI pada ibu post partum.

Tidak hanya daun katuk buah pepaya merupakan salah satu jenis tanaman yang baik untuk memperlancar ASI. Buah pepaya termasuk jenis buah yang sudah lama dikenal di tanah air. Pusat penyebaran pepaya diduga asli dari Meksiko bagian selatan hingga Nikaragua (Hamzah, 2014). Buah ini merupakan buah yang memiliki gizi tinggi. Dikatakan juga bahwa pepaya memiliki efek gastroprotektif, antibakterial, laksatif, dan laktagogum yang khasiatnya telah terbukti secara ilmiah dari buah pepaya (Muhartono dkk, 2018).

Kandungan laktagogum dapat menjadi salah satu cara meningkatkan laju sekresi dan produksi ASI untuk menanggulangi gagalnya pemberian ASI eklusif. Laktagogum secara langsung merangsang aktivitas protoplasma pada sel-sel sekretoris kelenjar susu dan ujung saraf sekretoris yang mengakibatkan sekresi air susu meningkat (Muhartono dkk, 2018).

$$
\text { Dalam penelitian yang }
$$

dilakukan Sri Banun dkk (2014) melakukan penelitian berjudul Pengaruh Buah Pepaya Terhadap Kelancaran Produksi ASI Pada Ibu Menyusui Di Desa Wonokerto Wilayah Puskesmas Peterongan Jombang Tahun 2014. Berdasarkan hasil penelitian dapat dilihat rata-rata frekuensi menyusui sebelum pemberian buah pepaya 5,7dan setelah mengkonsumsi buah pepaya mengalami peningkatan 9,75. Perbedaan rata-rata peningkatan produksi ASI sebelum dan sesudah perlakuan diperoleh nilai 4,05000 dengan sig 0,000 $(<0,05)$. Berdasarkan hasil penelitian dapat dilihat ratarata produksi ASI sebelum dan sesudah konsumsi buah pepaya berbeda. Dengan demikian dapat dinyatakan pemberian buah pepaya mempengaruhi peningkatan produksi ASI bagi Ibu menyusui.

Berdasarkan latar belakang di atas, maka peneliti tertarik untuk melakukan penelitian dengan judul: "Pengaruh buah pepaya terhadap kelancaran ASI diwilayah kerja Puskesmas Way Kandis Kota Bandar Lampung Tahun 2019"

\section{METODOLOGI PENELITIAN}

\begin{tabular}{ll}
\multicolumn{1}{c}{ Dalam penelitian in } \\
menggunakan jenis penelitian \\
kuantitatif.Rancangan
\end{tabular} penelitian menggunakan rancangan quasi. Populasi dalam penelitian ini adalah seluruh ibu post partum < 40 hari yang menyusui di Wilayah Kerja Puskesmas Way Kandis Kota Bandar Lampung yang berjumlah 80 orang pada bulan April-Juni Tahun 2019. Sampel pada penelitian ini adalah seluruh ibu nifas dan ibu menyusui yang memenuhi kriteria sampel dari bulan Januari-Maret tahun 2019 di Wilayah Kerja Puskesmas Way Kandis Kota Bandar Lampung Tahun 2019 sebanyak 30 responden yang didapat dari nilai rata-rata perbulan. Penelitian telah dilaksanakan pada hari senin tanggal 24 Juni sampai 1 Juli tahun 2019. Penelitian telah 
dilakukan di Wilayah Kerja Puskesmas Way Kandis Kota Bandar Lampung Tahun 2019. Variabel bebas adalah pemberian sayur buah pepaya. Variabel terikat adalah produksi ASI. Cara pengumpulan data dalam penelitian ini adalah dengan menggunakan data primer yaitu pasien atau ibu yang berkunjung saat dilakukan penelitian tentang pemberian sayur buah pepaya dengan kelancaran ASI, dengan menggunakan alat ukur lembar observasi berupa lembar ceklis yang berisi 8 indikator kelancaran ASI menurut (Maritalia, 2014) untuk melihat frekuensi ibu menyusui perhari dan anak tidak rewel dan mengetahui peningkatan produksi ASI.Pengumpulan data yang dipakai adalah observasi dengan melihat pengeluaran ASI (produksi ASI) sebelum dan sesudah dilakukan intervensi pemberian buah pepaya. Pada waktu pengambilan data responden diberi penjelasan terlebih dahulu mengenai tujuan dan kegunaan penelitian serta diminta kesediaannya untuk dilibatkan dalam penelitian ini. Analisa bivariat merupakan analisa yang dilakukan untuk melihat hubungan dua variabel (Notoadmodjo, 2018). Meliputi variabel bebas (pemberian buah pepaya) dan variabel terikat (produksi ASI). Dengan menggunakan uji T-test, dengan tingkat kepercayaan 95\% dan probabilitas pada taraf $5 \%$ untuk mengetahui pengaruh konsumsi buah pepaya terhadap peningkatan produksi ASI di Wilayah Kerja Puskesmas Way Kandis Kota Bandar Lampung Tahun 2019. Karena dari hasil uji normalitas data di peroleh sig <0,05, maka teknik statistik parametris yang digunakan untuk menguji komparatif sampel yang kedua datanya berbentuk ratio atau interval adalah $t$-test.

\section{HASIL PENELITIAN}

Tabel 1.

Distribusi Frekuensi Responden Berdasarkan Usia, Pendidikan, Pekerjaan

\begin{tabular}{|c|c|c|}
\hline Karakteristik & Jumlah & Persentase \\
\hline \multicolumn{3}{|l|}{ Usia } \\
\hline Reproduksi Tidak Sehat & 6 & 20.0 \\
\hline \multicolumn{3}{|l|}{ Pendidikan } \\
\hline SD & 1 & 3,3 \\
\hline SMP & 7 & 23,3 \\
\hline SMA & 16 & 53,3 \\
\hline PT & 6 & 20,0 \\
\hline \multicolumn{3}{|l|}{ Pekerjaan } \\
\hline Tidak bekerja & 20 & 66.7 \\
\hline Bekerja & 10 & 33.3 \\
\hline Jumlah & 30 & 100.0 \\
\hline
\end{tabular}

Berdasarkan Tabel 1 diketahui bahwa sebagian besar responden dalam rentang usia reproduksi sehat yaitu 20-35 tahun sebanyak 24 responden Produksi ASI Sebelum Intervensi

Tabel 2.
$(80,0 \%)$. responden berpendidikan SMA yaitu 16 responden $(53,3 \%)$, responden tidak bekerja yaitu 20 responden $(66,7 \%)$.

Kelancaran ASI Pada Ibu Nifas Sebelum Pemberian Buah Pepaya 


\begin{tabular}{ccccc}
\hline Pengukuran & Mean & Median & Sdt Dev & Min-Max \\
\hline Sebelum & 2.87 & 3 & 1,137 & $1-5$
\end{tabular}

Tabel diatas didapatkan bahwa ratarata produksi ASI sebelum tindakan adalah 2.87, median 3 , dengan

\section{Produksi ASI Sesudah Intervensi}

Tabel 3.

Kelancaran ASI Pada Ibu Nifas Sesudah Pemberian Buah Pepaya

\begin{tabular}{ccccc} 
& & \multicolumn{2}{c}{$\mathrm{n}=30$} \\
\hline Pengukuran & Mean & Median & Sdt Dev & Min-Max \\
\hline Sesudah & 5,97 & 6 & 1,22 & $3-8$ \\
& & & & \\
\hline
\end{tabular}

Tabel diatas didapatkan bahwa ratarata produksi ASI sesudah tindakan adalah 5,97 , median 6 , dengan

\section{Analisis Bivariat}

standar deviasi 1,22 , skor minimal 3 dan maksimal 8.

standar deviasi 1,137, skor minimal 1 dan maksimal 5.

\section{Tabel 4.}

Pengaruh Pemberian Buah Pepaya Terhadap Kelancaran ASI pada ibu nifas

\begin{tabular}{lccccc} 
& & & \multicolumn{3}{c}{$\mathrm{n}=30$} \\
\hline Kelancaran Produksi ASI & Mean & Beda Mean & Std Dev & SE & P value \\
\hline Sebelum & 2.87 & $-3,1$ & 1.137 & 0.208 & 0,000 \\
Sesudah & 5.97 & & 1.217 & 0.222 & \\
\hline
\end{tabular}

Dari tabel 4.diatas terlihat bahwa rata-rata produksi ASI sebelum tindakan adalah 2.87, sedangkan rata-rata produksi ASI sesudah tindakan adalah 5,97. Hasil uji statistik didapatkan nilai 0,000 (P value $=0,000$, dimana $P$ value $<a$

\section{PEMBAHASAN}

\section{Analisa Univariat}

\section{a. Produksi ASI Sebelum Diberikan \\ Buah Pepaya}

Berdasaarkan tabel 1, diketahui bahwa rata-rata (mean) produksi ASI sebelum diberikan buah pepaya $\mathrm{Di}$ Wilayah Kerja Puskesmas Way Kandis Kota Bandar Lmpung Tahun 2019 adalah 2,87 dan standar deviasi 1.137.

Secara teori faktor penghambat dalam pemberian ASI adalah produksi ASI itu sendiri. Produksi ASI yang
$(0,05)$ maka dapat disimpulkan ada pengaruh mengkonsumsi sayur buah pepaya terhadap produksi ASI pada ibu menyusui Di Wilayah Kerja Puskesmas Way Kandis Kota Bandar Lampung Tahun 2019.

kurang dan lambat keluar dapat menyebabkan ibu tidak memberikan ASI pada bayinya dengan cukup. Selain hormon prolaktin, proses laktsi juga bergantung pada hormon oksitosin, yang dilepas dari hipofise posterior sebagai reaksi terhadap penghisapan puting. (Kodrat, 2010).

Berdasarkan hasil penelitian dan pembahasan diatas, sejalan dengan penelitian Sri Banun Titi Istiqomah (2015) yang menyebutkan bahwa hasil penelitian dapat dilihat bahwa produksi ASI sebelum konsumsi 
sayur buah pepaya rata-rata frekuensi menyusui adalah 5,7 kali dengan standar deviasi 0,80131 dan setelah mengkonsumsi buah pepaya rata-rata frekuensi menyusui mengalami peningkatan menjadi 9,75 kali dengan standar deviasi 0,78640. Kolerasi antara dua variabel adalah sebesar 0,793 dan perbedaaan nilai rata-rata peningkatan produksi ASI pada ibu yang tidak mengkonsumsi dan yang mengkonsumsi buah pepaya adalah

\section{Analisa Bivariat \\ a.Produksi \\ ASI Sesudah \\ Diberikan Buah Pepaya \\ Berdasarkan tabel 4.6 diketahui} bahwa di Wilayah Kerja Puskesmas Way Kandis Kota Bandar Lampung Tahun 2019, rata-rata produksi ASI sebelum diberikan buah pepaya 2,87 dengan standar deviasi 1,137 dan rata-rata produksi ASI sesudah diberikan buah pepaya 2,97dengan standar deviasi 1,22. Berdasarkan hasil uji T-test didapatkan nilai ( $p$ value $=0,000)$, artinya lebih kecil dari nilai a $(0,05)$. Dengan demikian dapat disimpulkan secara statistik dengan derajat kepercayaan 95\% menunjukkan ada pengaruh mengkonsumsi sayur tumis buah pepaya terhadap produksi ASI pada ibu menyusui Di Wilayah Kerja Puskesmas Way Kandis Kota Bandar Lampung Tahun 2019.

Pepaya sebagai salah satu buah yang mengandung laktagogum merupakan buah tropis yang dikenal dengan sebutan Carica papaya. Buah pepaya juga merupakan salah satu jenis buah yang memiliki kandungan nutrisi tinggi dan kaya akan manfaat bagi kesehatan. Pepaya muda (Carica papaya $L$ ) merupakan salah satu laktogogum alternatif yang tepat untuk di manfaatkan oleh masyarakat. Hal itu dikarenakan banyak dijumpai di wilayah Indonesia dan bisa diperoleh dengan harga yang relatif murah, serta proses budidaya
4,05000 dengan sig 0,000. Karena sig $<0,05$, maka berarti bahwa rata-rata produksi ASI sebelum dan sesudah konsumsi buah pepaya adalah berbeda. Dengan demikian dapat dinyatakan bahwa pemberian buah pepaya dapat mempengaruhi peningkatan produksi ASI ibu menyusui di Desa Wonokerto di wilayah Puskesmas Peterongan Kabupaten Jombang.

yang tergolong mudah untuk dilakukan (Sri Banun dkk, 2015)

Air buah pepaya muda memberikan efek meningkatkan jumlah dan diameter kelenjar mama. Getah (lateks) dari buah papaya muda memiliki efek sama dengan oksitosin pada uterus. Hormon prolaktin dan oksitosin berperan dalam peningkatan produksi air susu. Prolaktin berperan dalam sintesis air susu, sedangkan oksitosin berperan merangsang mioepitel disekitar alveolus untuk berkontraksi sehingga semprotan ASI dapat diteruskan melalui duktus (Manuaba, 2012).

Hasil penelitian ini selaras dengan hasil penelitian Istiqomah (2015) tentang Pengaruh Buah Pepaya Terhadap Kelancaran Produksi ASI Pada Ibu Menyusui Di Desa Wonokerto Wilayah Puskesmas Peterongan Jombang Tahun 2014, menunjukkan hasil penelitian dapat dilihat bahwa produksi ASI sebelum konsumsi buah pepaya rata-rata frekuensi menyusui adalah 5,7 kali dengan standar deviasi 0,80131 dan setelah mengkonsumsi buah pepaya rata-rata frekuensi menyusui mengalami peningkatan menjadi 9,75 kali dengan standar deviasi 0.78640 . Kolerasi antara dua variabel adalah sebesar 0,793 dan perbedaan nilai rata-rata peningkatan produksi ASI pada ibu yang tidak mengkonsumsi dan yang mengkonsumsi buah pepaya adalah 4,05000 dengan sig 0,000. Karena sig $<0,05$, maka berarti bahwa rata-rata 
produksi ASI sebelum dan sesudah konsumsi buah pepaya adalah berbeda. Dengan demikian dapat dinyatakan bahwa pemberian buah pepaya dapat mempengaruhi peningkatan produksi ASI ibu menyusui di Desa Wonokerto di wilayah Puskesmas Peterongan Kabupaten Jombang.

Tanaman pepaya merupakan tanaman yang banyak digunakan oleh masyarakat sejak dulu. Senyawa aktif yang terkandung di dalamnya yaitu enzim papain, karotenoid, alkaloid, flavonoid, monoterpenoid, mineral, vitamin, glukosinolat, dan karposida vitamin C, A, B, E, serta mineral. Dikatakan juga bahwa pepaya memiliki efek gastroprotektif, antibakterial, laksatif, dan laktagogum yang khasiatnya terlah terbukti secara ilmiah dari buah pepaya. Kandungan laktagogum (lactagogue) dalam pepaya dapat menjadi salah satu cara untuk meningkatkan laju sekresi dan produksi ASI dan menjadi strategi untuk menanggulangi gagalnya pemberian ASI eksklusif yang disebabkan oleh produksi ASI yang rendah.

Mekanisme kerja laktagogum dalam membantu meningkatkan laju sekresi dan produksi ASI adalah dengan secara langsung merangsang aktivitas protoplasma pada sel-sel sekretoris kelenjar susu dan ujung saraf sekretoris dalam kelenjar susu yang mengakibatkan sekresi air susu meningkat, atau merangsang hormon prolaktin yang merupakan hormon laktagonik terhadap kelenjar mamae pada sel-sel epitelium alveolar yang akan merangsang laktasi.

Berdasarkan hasil penelitian dan pembahasan diatas didapatkan bahwa dengan mengkonsumsi sayur buah pepaya dapat meningkatkan produksi ASI bagi ibu menyusui. Namun dalam hasil penelitian ini, dari 30 responden peneliti mendapatkan sebanyak 6 orang ibu memiliki nilai tetap yang ASI nya tidak lancar setelah dilakukan terapi pemberian sayur buah pepaya. Hal ini disebabkan oleh faktor umur, kurang fokusnya ibu saat dilakukan terapi, pengaruh dari pengetahuan ibu yang kurang dan faktor pekerjaan ibu. Ibu yang diberi sayur tumis buah pepaya menolak untuk mengkonsumsinya dan ibu tidak bersikap kooperatif kepada peneliti.

\section{Kesimpulan}

1. Rata-rata produksi ASI sebelum tindakan adalah 2,87

2. Rata-rata produksi ASI sesudah tindakan adalah 5,97

3. Hasil uji statistik didapatkan nilai $0,000(P$ value $=0,000$, dimana $P$ value < a $(0,05)$ maka dapat disimpulkan ada pengaruh mengkonsumsi sayur buah pepaya terhadap produksi ASI pada ibu menyusui Di Wilayah Kerja Puskesmas Way Kandis Kota Bandar Lampung Tahun 2019

\section{Saran}

1. Bagi Akademik, Penelitian ini hendaknya dapat menambah referensi mahasiswa tentang peningkatan produksi ASI, sehingga mahasiswa dapat meningkatkan kemampuannya agar terampil dalam memberikan konseling tentang pentingnya membantu ibu menyusui dalam peningkatan produksi ASI sehingga dapat meningkatkan pemberian ASI eksklusif.

2. Bagi Tempat Penelitian, petugas kesehatan agar lebih meningkatkan keterampilan melalui literatur terbaru, pelatihan serta konseling pada setiap pemeriksaan ibu hamil, sehingga memiliki pengetahuan tentang manfaat yang cukup terhadap buah pepaya dalam meningkatkan produksi ASI.

3. Bagi Peneliti Lain, Diharapkan agar peneliti lain dapat melanjutkan penelitian ini dengan 
faktor-faktor lain yang dapatmeningkatkan produksi ASI seperti: sayurkatuk, labu siam, kacang panjang dan buah buahan yang mengandung banyak air akan membantu ibu menghasilkan ASI yangberlimpah, seperti melon, semangka, pear, dan banyak lagi buah-buahan berair sertabanyak faktor lain, seperti psikologi,pelaksanaan Inisiasi Menyusu Dini (IMD),status gizi dan penggunaan alat kontrasepsi.

\section{DAFTAR PUSTAKA}

Ambarwati., Retna. E., Wulandari. D. (2010). Asuhan kebidanan nifas. $\quad$ Edisi

Kelima. Yogyakarta: Nuha Medika.

Dinas Kesehatan Kota Bandar Lampung (2018). ASI Ekslusif 2018. Bandar Lampung

Hamzah. A. (2014). 9 Jurus Sukses Bertanam Pepaya California. Agromedia.

Kementrian Kesehatan Republik Indonesia (2017). ASI Ekslusif 2017. Jakarta : Kementrian Kesehatan Republik Indonesia diunduh dari

http://www.depkes.go.id pada tanggal 19 November 2018

Kharisma., Yuktiana., Armaya, A., Herri S. (2011). Efek ekstrak air buah pepaya (Carica papaya L.) muda terhadap gambaran histologi kelenjar mamma mencit laktasi. Majalah Kedokteran Bandung.

Kodrat, L. 2010. Dahsyatnya ASI dan Laktasi. Yogyakarta: Media Baca
Istiqomah, S. B. T., Wulanadari, D. T., \& Azizah, N. (2015). Pengaruh Buah Pepaya terhadap Kelancaran Produksi ASI pada Ibu Menyusui di Desa Wonokerto Wilayah Puskesmas Peterongan Jombang Tahun 2014. Eduhealth, 5(2).

Manuaba, I. A. C. IBG Fajar M., I. BG Manuaba, 2012. Ilmu Kebidanan, Penyakit Kandungan dan KB untuk Pendidikan Bidan Edisi, 2.

Maritalia, D. (2014). Asuhan kebidanan nifas dan menyusui. Edisi Kedua. Yogyakarta: Pustaka Pelajar.

Maryunani, A. (2012). Inisiasi menyusui dini, ASI eksklusif dan manajemen laktasi. Jakarta: Tim.

Muhartono, M., Risti, G., Heidy, P. (2018) "Pengaruh Pemberian Buah Pepaya (Carica Papaya L.) terhadap Kelancaran Produksi Air Susu Ibu (ASI) pada Ibu Menyusui. Jurnal Medula 8.1

Notoatmodjo, S. (2018). Metodologi penelitian kesehatan (Cetakan VI). Jakarta: Penerbit PT. Rineka Cipta.

Peraturan Pemerintah No. 33 tahun 2012 tentang Pemberian Air Susu Ibu Ekslusif. Diiunduh dari

http://www.hukor.depkes.go .id/

Riset Kesehatan Dasar Kementrian Kesehatan Republik Indonesia (2018). Kesehatan Anak 2018. Diunduh dari http://www.depkes.go.id/ pada tanggal 21 Februari 2019 
Saleha, S. (2009). Asuhan kebidanan pada masa nifas. Jakarta: Salemba Medika.

Sri B., Triloka D., Azizah. (2015). Pengaruh Buah Pepaya Terhadap Kelancaran Produksi ASI Pada Ibu Menyusui Di Desa Wonokerto Wilayah Puskesmas Peterongan Jombang Tahun 2014. Eduhealth 5.2.

Survei Demografi dan Kesehatan Indonesia (2017). Angka Kematian Bayi tahun 2017. Diunduh dari https://ekoren.bkkbn.go.id/ pada tanggal 14 Februari 2019.

UNICEF. (2018). Infant AND Young Child Feeding. Di unduh dari https://data.unicef.org/topic /nutrition/infant-and-youngchild-feeding/

Wardiyah, A., Rilyani. (2016). Sistem reproduksi. Jakarta: Salemba Medika.

Wardiyah, A., Wandini, R., Suryani, S. (2018). Penyuluhan Pentingnya ASI Ekslusif Di Posyandu Mawar Pekon Sidomulyo Wilayah Kerja Puskesmas Pagar Dewa Lampung Barat Tahun 2017. Jurnal Kreativitas Pengabdian Kepada Masyarakat. 